\title{
Beyond Paper-Based Affiliate Status: Policy Analysis on Non-Formal Education and the Graduates in Ethiopian Higher Education Institutions
}

\author{
Mulu Bzayene* \\ College of Social Science and Humanities, Raya University, PO Box 92, Tigray, Ethiopia \\ Teklu G/medhin \\ College of Social Science and Humanities, Raya University, PO Box 92, Tigray, Ethiopia
}

\begin{abstract}
Non-formal education is a form of education that creates access to education for adults in remote rural areas, people living with disabilities, prison inmates etc. to acquire knowledge, skill and attitude that would make them to be independent of their own. This paper aims to critically analyze the applicability of non-formal education in higher education institutions in Ethiopia. In doing so, the researchers employed qualitative research approach to analyze the existing national documents regarding non-formal education program in higher education institutions. This paper, accordingly, reveals that Ethiopian higher education institutions/ universities use necessarily the same educational policy and curriculum, both for formal and non-formal education programs. Their academic vacancies, however, unequivocally excluded the non-formal education program graduates from university lectureship competition. In other words, though the formal and non-formal education students graduated from the same institution, and learn by the same curriculum (harmonized one), by the same academic staff and evaluated through the same mode of assessment and grading system and pass through the same certification procedure, the later ones are ineligible to be lecturers in higher education institutions. In conclusion, there is educational inconsistency between policy and practice in Ethiopian higher education institutions. Accordingly, the researchers recommend that job vacancies in higher education institutions for lectureship should bases on the competence of the applicants.
\end{abstract}

Keywords: Educational policy, Higher Education Institution, Lectureship, Non-formal Education, Quality education

DOI: $10.7176 / \mathrm{JEP} / 10-10-08$

Publication date: April $30^{\text {th }} 2019$

\section{Introduction}

Higher education is an interdisciplinary subject offered to students who attend in first degree, second degree and a doctoral degree in regular, continuing and distance education programs. Mill clearly articulated that higher education is an institution where knowledge is pursued, intelligence is perfected and the culture of pursuing knowledge, skill and attitude is acquired (Pring, 2004). Higher education institutions are, therefore, established to produce creative, skilled and engaged society through scientific map of teaching method, preparing scientific and agreed literary standard teaching materials, meeting the urgent needs of the youth and provide researchbased response to the call of society to produce the worthy and productive citizen in the country. In order to do this and to provide access to education to all individuals in urban and rural areas and to produce highly qualified man power that could satisfy their incremental demand of intake capacity, they could launch all higher education programs.

In Ethiopia, the idea of higher education was introduced in 1960s; albeit access to higher education was limited. This was because of lack political commitment of the governments to expand equitable access to higher education throughout the country. Besides, the educational policy has been changed from regime to regime (Negash, 2006). During the imperial regime, the educational policy was aimed at inculcate the value of imperialism (Negash, 2006). While the aim of education during the military regime was to "cultivate MarxistLeninist ideology in the young generation, to develop knowledge in science and technology, and to integrate and coordinate research with production so as to enable the revolution to move forward and secure productive citizens". The number of higher education students was estimated 6,474 in 1973 and 18,000 thousand in 1991 (Negash, 2006).

In the later 1990s, the government launched new education policy and the idea of higher education is changed. Since then, the establishment of both public and private universities was proclaimed aimed to produce skilled man power in quality and quantity, to conduct problem solving researches and provide community services benefits for the society's prosperity (MOE, Proclamation No. 351/2003 , 2003). At this time, the number of students in higher education institutions grew alarmingly and estimated as 147, 954 (MOE, Educational Statistics Annual Abstrat, 2002/3). 
After these ups and downs, it is at recent time that equitable access and relevant higher education has opened to the wider population of the country. Within a decade, the number of public higher education institutions grew by five times. Private higher education institutions have also expanded and reached more than hundred with 15 per cent enrollment capacity. Totally, the estimation number of higher education students has reached millions enrolled at degree, master's and doctoral programs at all educational system (Abiyot, 2016).

To respond the increasing number of students, the intake capacity of higher education institutions is rapidly increasing. In doing so, non-formal education programs (distance, summer and evening) are recognized as one education program in higher education institutions which creates a lifelong learning opportunity for the wider society of the country and accordingly to develop their personal, societal and economic aspects. In 2004, for instance, various types of in-service programs such as distance education, extension classes and summer programs were expanded to cope with the shortage of supply of qualified man power (MoE, ESDP IV, 2010).

Similarly, to produce qualified and skilled man power in all fields of study, the Ministry of Education has designed harmonized education curriculum for all higher education programs, adopted modular approach of course delivery to enhance active learning and instituted quality education assurance and enhancement offices at all higher education institutions in the country. Justifiable educational administration and qualified, skilled and experienced professionals and teachers, regardless of the educational program, could assure quality education in higher education institutions. As noted above, harmonized education curriculum is intended to assure and enhance quality education and to produce well-equipped and competent professionals in higher education institutions in Ethiopia (HEP, 2009).

Despite these efforts, non-formal education graduates are considered ineligible to compete for lectureship at higher education institutions in Ethiopia. Perhaps, the form of the program they graduated from is the reason for their exclusion from academic staff competition in higher education institutions.

The focus of this article is not however to deal with all theoretical and practical issues of higher education institutions rather it focuses on the status of non-formal education program as a form of higher education program vis-à-vis the academic profile of the graduates in higher education institutions in explaining educational paradox between policy and practice in higher education institutions in Ethiopia.

The aim of this paper is therefore to analyze the following issues. Interdependency of formal and nonformal education; curriculum of non-formal education (mode of course delivery, assessment and grading system, instructors' academic rank, course content and teaching material, time duration, graduate profile and competency certification system; placement criteria and procedure of academic staff in higher education institutions; policy affiliation of non-formal with formal education.

In an attempt to deal with these issues, the paper draws on the already existing experiences, academic legislations and vacancies as exercised by higher education institutions and Ministry of Education and on available literatures. With a view to provide a realistic account of the status of the program, the authors have exerted their effort to access the available documents and attempted to review the proclamations, legislations and vacancies as well as legal documents addressed by the government in general and higher education institutions in particular regarding non-formal education program and its graduates. These issues are reviewed with a view to provide policy and practical proportions of non-formal education program in higher education institutions in Ethiopia. Apart from this, non-formal education, for the purpose of this paper, is program offered in continuing and distance education such as distance, evening and summer programs.

\section{Historical Development of the Idea of Education: An overview}

Education was primarily the concern of churches prior to the $16^{\text {th }}$ century. Parents were responsible make their children learn spiritual education. Since the age of enlightenment, John Locke and Jean-Jacques Rousseau referred the necessity of modern conception of education. At this time, education became a matter of public concern and in response states took the primarily responsibility to expand modern education at least within their jurisdictions (Marginson, 2008).

Since the emergence of socialism and liberalism, education becomes the decisive realm of human rights in the world. In the $19^{\text {th }}$ century, the liberalists criticized the religious conception of education and advanced the idea of freedom of science, research and teaching against church and state interference. At the second half of the $19^{\text {th }}$ century, education was recognized as constitutional right of the citizens of German Empire (Abiyot, 2016). After the end of the First World War, education was recognized as part and parcel of human rights at the international level. For instance, the Proclamation of the Declaration of Geneva, the so-called "Charter of Child Welfare of the League of Nations" in 1924 led to an international recognition of the right to education (Singh, 1991).

In this globalized world, all aspects of education are clearly enshrined in constitutions and legislations of the world states including Ethiopia, Spain, Vietnam, Ireland, Egypt, Japan, Paraguay and Poland, to mention some (Hodgson, 1998). Education is more than just learning how to read, write or calculate. Being educated is to be, at least, in possession of understandings, knowledge, skills and dispositions whereby one makes sense of the world 
around (Pring, 2004). It is "the initiation of young people into those worthwhile forms of knowledge which, when not narrowly conceived, illuminate experience in its different manifestations and forms. And that is relevant to all young people, not just a selected few". To educate is then to enable those young people to understand the variety of experience to be shared and made sense of the world (Pring, 2004).

Any development effort without future-oriented educational policy is, therefore, impossible. On the one hand, it enables societies acquire knowledge, skill and attitude and accordingly participate in the overall development activities of their country and it makes a significant contribution to address sustainable human development and to determine the direction of the growth of the society in the future on the other. These educational contributions become visible in schools, colleges and universities in Ethiopia since 1994 (ETP, Educaonal Policy and Training, 1994).

\section{The Role of Higher Education in human Capital Development}

Human capital development is a key engine and crucial input for development endeavor. To promote human capital development expansion of educational institutions at all grade level plays paramount role. Especially higher education institutions are potential to deliver specialized trainings for a large number of students in different educational programs at all tertiary levels of education. The centerpiece of training in higher education institution is providing knowledge based, skills, and training to perform specific tasks and jobs (Thomson, 2008). In economic terms, "human capital" adds higher levels of education and competency to the national capacity for economic growth.

Moreover, higher education institutions deliver their training program in a diversified manner to enhance their intake capacity and reach the community at large to serve their educational demand and aspiration. This creates great opportunity for students, the community and the government. Students get an opportunity to upgrade their educational qualification in different programs (distance, evening and/or summer) in their interest of specialization without interrupting their career, family attachment and financial constraint. In addition they may enjoy salary increment in their job and get further chance to be competent for other higher level employment vacancies. As a result the community will have better chance to serve by qualified and knowledgeable professionals in all aspects of their life in all sectors (MoE, ESDP IV, 2010).

The government is also profitable in which it creates high skilled man power which is necessary input to discharge institutional duties and responsibilities. Especially in the case of teaching profession, teachers need to get an opportunity to take further training after their graduation and upgrade their professional qualification. To ensure this objective the expansion of non-formal education training opportunities contribute crucial role. Thus, the government of Ethiopia recognizes such programs in different education sector development programs $(\mathrm{MoE}$, ESDP V, 2015).

\section{Teachers' Professional Development}

In order to improve the qualification of teachers at primary as well as secondary level various teacher support activities have been undertaken. The Teacher Education System Overhaul (TESO) Program is undertaking a thorough revision and modernization of the teacher education system in Ethiopia. Accordingly large numbers of teachers have started their summer degree program training in order to upgrade their qualifications. During the past ten years it has undergone major quantitative and qualitative change among teachers. A succession of new policies was designed and implemented, with the Education and Training Policy (1994) being the first major framework for systems reform and transformation (ETP, Educaonal Policy and Training, 1994). The policy stressed issues of quality and relevance in educational programs and emphasized the linkage of higher education institution's contribution and the country's development.

To this end different education sector development programs are prepared as a means to implement the education and training policy of the country which introduces action plan programs at five year interval since 1996. As a result non-formal education programs are widely practiced in higher education institutions so as to upgrade the quality and competence of teachers at different levels of education.

\section{Non-formal Education in general}

Learning is a guided and systematic activity of acquiring knowledge which is beyond the scope of activities take place in schools and other educational institutions. This is to mean, the goal of learning is to accumulate knowledge, no matter the program and method it could be acquired, and get officially certified (Moran, 2008). This shows, nothing shapes human capital more than education because it drives prosperity and enables people to enjoy productive and rewarding working lives (Marginson, 2008).

The definition of non-formal education is still subject to controversy. Its nature and scope varies from state to state. Non-formal education "denotes the entire body of ongoing learning processes, formal or otherwise, whereby people regarded as adults by the society to which they belong develop their abilities, enrich their knowledge, and improve their technical or professional qualifications or turn them in a new direction to meet 
their own needs and those of their society" (UNESCO, 1997). As cited in O.Olaniyi, Afrik defines non-formal education based on the aim of the education. So, if it aims to produce an individual who is honest, respectable, skilled, and cooperative, it is referred as traditional non-formal education and contemporary non-formal education if the aim is all-available educational activities organized for adults without legal pressure (O.Olaniyi, 2015).

In Nigeria, for instance, non-formal education is a program that covers literacy, vocational technical education, open apprenticeship, labor education, continuing education for remedial purposes (early school leavers) and professional competence building and upgrading of skills and academic status (O.Olaniyi, 2015). This definition is based on the contemporary definition of non-formal education.

Carron and Carr-Hill summarize the distinctions between formal and non-formal education. Formal education is the institutionalized, chronologically graded and hierarchically structured education system, running from lower primary school to the upper reaches of the higher education, generally full time and sanctioned by the state. Whereas non-formal education comprises all educational activities organized outside the formal system and designed to serve identifiable clientele and educational objectives with all remaining educational activities" (Carron \& Hill, 1991).

Schooling for adults who have never been to school or whose schooling has been exceedingly limited also tends to be labeled "non-formal". In many countries, during the last two decades, governments have established departments of non-formal education as part of their ministries of education program and have given these departments responsibility for all adult and out-of-school education, with a vague responsibility for cocoordinating adult education activities carried out by other ministries. Often the main focus of their work is adult literacy and continuing education, parallel to the formal system, for school leavers and dropouts (Carron \& Hill, 1991).

Pointing out this, non-formal education, like formal ones, is based on a commitment to learning and knowledge acquisition, and scientifically sound curriculum and human resources (Russell, 2001). It was among the basic tools of education in any society decades ago. It is organized, planned and structured and serves identifiable clientele, and has clearly defined educational objectives. As a result it has its own share to enhance an individual's personality and provides confidence to reach out to the world and to make man relevant and functional in a dynamic society (Escrigas, 2008).

However, it has been seen as lesser importance in comparison to formal education due to lack of recognition in the wider academic society such as higher education institutions. Due emphasis is given to lifelong learning of higher education especially in the developing nations of the world until it has recognized as a significant component of higher education in the $21^{\text {st }}$ century (O.Olaniyi, 2015).

Since then, various developmental agencies and organizations are devoted to promote non-formal education as of its major role in ensuring that all people in the society are educationally catered for cannot be underestimated (O.Olaniyi, 2015). Similarly, European countries like UK, Australia and France recognized nonformal education and incorporated in their education policy. In this sense, non-formal education has equal weight with the formal ones. Accordingly, higher education institutions started to recognize non-formal education alongside academic achievements in their recruitment and acceptance of new students as well as placement procedure of academic staff. Here, both forms of education are never be substituted each other rather benefit each other and work together.

To date, non-formal education becomes a form of education and it creates educational room for adults in remote rural areas, people living with disabilities, prison inmates etc. to acquire knowledge, skill and attitude that would make them to be independent of their own. Its expansion is, therefore, part of exerted efforts states to create knowledge-based society, to cope with the competitiveness successfully and to take the advantage of the possibilities offered by new technologies and improve social cohesion in the world.

\section{Non-Formal Education in HEIs in Ethiopia}

Higher education institution can be defined as an interdisciplinary education institution offered to students who attend first degree, second degree or medical specialty and/or a doctoral degree" in regular, distance, evening and summer programs ${ }^{2}$ after they have completed secondary education. Higher education institutions' core role remains the provision of quality education, dissemination of higher quality, openly disseminated, research as well as community services. When they undertake research that has practical applications, it is knowledge and technology transfer, diffusion and utilization that matters in terms of community well-being (Marginson, 2008).

The training given by higher education institutions plays important role in human, social, and economic development (Escrigas, 2008). The role of higher education institutes (HEIs) in development is vital, but it is also complex, fluid and dynamic. HEIs exhibit numerous different capabilities and scope, and can affect

\footnotetext{
${ }^{1}$ Article 2 (1) of the Higher Education Proclamation No. 351/2003, Addis Ababa, Negarit Gazette, 2003

${ }^{2}$ Ibid, Article 5
} 
processes of development both directly and indirectly through teaching, research and community service.

More recently, the social and economic role of HEIs in development has regained prominence in the development agenda. For instance, the UN views higher education as integral part to all aspects of development such as environmental awareness and sustainability, post-conflict resolution, poverty alleviation, cultivating values such as human rights, health care issues, and cultural preservation or change. HEIs are expected to cultivate certain values and understanding of issues that facilitate both economic and social development. To this end higher education institutions should produce highly competent and skillful professionals in all their programs (Moran, 2008).

In Ethiopia, non-formal education is recognized to be integrated with basic education at all levels of formal education as educational strategy of satisfying the country's need for skilled man power in 1994 (ETP, Educaonal Policy and Training, 1994). In addition, it plays a major role to create knowledge-based society by giving lifelong learning opportunities that meets the diverse learning needs of all especially to those living in remote areas and have not equal access to education at all levels and contributes to personal, societal and economic Development.

Expansion of higher education institutions has been undertaken to satisfy the demand for highly qualified and skilled labor in the country. As part of higher education, six universities were established and reached eight public universities to implement the first and second education sector development program in the country. As a result, the total annual intake capacity of the higher education institutions has increased from 9,067 in 1996/97 to 31,997 degree program students in 2004/05.

Even though, it is in 2005 that the Ethiopian government concerned to encourage non-formal education (distance education) in all higher education institutions. This is mainly part of the overall strategy of higher education institutions in the country. The strategy is to provide good quality higher education to a large number of students equitably and based on merit so as to meet the demand of the economy and the country at large. The number of public higher education institutions in Ethiopia was eight and the total annual intake capacity was estimated 32 thousand students in regular program in 2004. As part of expansion, thirteen public higher education institutions were established with the expectation of reaching the total annual intake capacity of the country to 110 thousands in 2010. In addition, private higher education institutions are encouraged by expectation to increase the total annual intake capacity in first degree programs in the country.

In order to meet the demand for qualified academic staff in higher education institutions, ESDP III (2005) has prioritized the development of post-graduate training programs. This priority was to increase the enrolment in post-graduate program from 3,884 to 26,000 in 2009 as a response to the rapid evolvement of undergraduate enrolment in the country. Even though, the number of academic staff has increased from 3,884 to 11, 238 in 2009 the achievement is less than half of the proposed number.

At the same time, distance mode of education was encouraged as a means to expand access to higher education in Ethiopia in 2005. Higher education institutions have developed their distance education provision procedures. Accordingly, it shares 12.6 per cent from the total annual enrollment rate of higher education institutions in 2009. This shows that, access to higher education remains limited to 5.3 per cent, post-graduate admissions remain far below that the target figures, distance education remains hardly developed and there was shortage of qualified academic staff in higher education institutions by the end of ESDP III.

The undergraduate intake capacity of higher education institutions increased from 447, 693 in 2010/2011 to 593,571 students in 2014/2015. Of these, $57 \%$ of them are enrolled in regular undergraduate program and $43 \%$ of them are enrolled in non-formal education that is a combination of distance, summer and extension programs. Similarly, total annual intake capacity of masters' enrolment in public higher education institutions increased from 7,211 in 2007/08 to 27,643 in 2013/14. In addition, private higher education institutions have expanded and reached 98 institutions, and then began enrolling postgraduate students and they accommodate 3,000 Master's students and the total enrolment reached 30,643 in 2014.

However, the issue of accessing qualified teaching staff in higher education institutions has not kept rapidity with the increase in student enrolment. Though it was planned to have zero bachelor degree academic staff to be succeed in 2014, the large share of undergraduate students are taught by Bachelor degree instructors especially science and technology students.

\section{Quality Education in HEIs}

Education is not a mere reflection of the social and economic forces at work in a society. It is also an important means of shaping the socio-economic and cultural forces and determining the direction of their growth. The dynamism of these other forces in turn affects the character of education. Thus, there is circularity in the interrelation of education and a range of other human and societal factors. The consequences of education for society are mediated essentially through individuals affected by education and become deeper as the mediating agencies acquire collective possibilities over time. Thus, it is a very important factor to human development. (Singh, 1991). 
According to the 1994 Education and Training Policy, education "is a process by which we transmit, "experiences, new findings and values accumulated over the years. It also enables individuals and society to make all-rounded participation in the development process by acquiring knowledge, ability, skills and attitudes". This could only be possible when there is quality education at all a level of education. In doing so, higher education institutions have a major role to improve and enhance quality education in the primary, secondary and tertiary level of education.

Higher education plays a necessary and an increasingly important role in human, social, and economic development (Escrigas, 2008). In pursuit of development goals in a country could largely address with scientific contribution of higher education institutions by providing adequate education and reciprocally by improvements in higher education that increase the impact, quality and effectiveness of higher education institutions' role in development and social change.

In the early $20^{\text {th }}$ century, higher education was usually limited to universities, which often had a conception of "true education" as a purely academic endeavor, and not directly relevant to local communities. Community service was left primarily to government programs (Hanson 1966).

Higher education institutions include public and private universities and colleges. Higher education is an interdisciplinary education offered to students who attend diploma, first degree, second degree or medical specialty and/or a doctoral degree" ${ }^{3}$ in regular, distance, evening and summer programs ${ }^{4}$ after they have completed secondary education. Higher education institutions' core role remains the provision of quality education, dissemination of higher quality, openly disseminated, research as well as community service. When they undertake research that has practical applications, it is knowledge and technology transfer, diffusion and utilization that matters in terms of community well-being (Marginson, 2008). In this context, higher education is about empowerment and raising the quality of life where people can continue to develop their knowledge and skills. It is about learning to know, learning to do, learning to be, and learning to live together (Carron \& Hill, 1991).

In Ethiopia, quality higher education has been a priority issue of education sector development program especially since 1994. Because of this, the government was committed to revise the curriculum to make relevant to children's experience and environment, to establish quality assurance mechanisms to monitory students achievement, to arrange school improvement program, to intensify pre-service and in-service training of teachers to produce qualified and committed teachers in 2005 (MoE, ESDP III, 2005). Even though, the graduation rate of regular undergraduate students is as low as $79 \%$. Low quality of instruction, low relevance of the higher education courses, and low quality of students introduced to higher education and low quality of teaching in higher education institutions are identified as causes for the low graduation rate of students from the institutions.

To address these problems and to improve quality education in higher education, effective and efficient implementation of curriculum, qualified and committed teachers are essential. To produce qualified teachers, distance education and in-service training programs are institutionalized in addition to regular post-graduate programs in all higher education institutions in the country, except the newly emerging ones. As part of quality education enhancement efforts, harmonizing curricula for all of the higher education is introduced, modular approach for course delivery is adopted, and quality assurance offices at each higher education institutions are instituted.

\section{Status of Non-Formal Education in HEIs in Ethiopia}

Ethiopian government formulated education and training policy that demands both formal and non-formal education at all levels of education sector (ETP, Educaonal Policy and Training, 1994). In terms of objective, the policy targets to promote relevant and appropriate education and training through formal and non-formal programs (ETP, Educaonal Policy and Training, 1994).

Accordingly, non-formal education (distance education) has been recognized as a form of education since 2005. It becomes part of educational strategy designed to provide good quality higher education to a large number of students equitably and based on merit so as to meet the demand of the economy and the country at large. Then higher education institutions have developed their distance education provision procedures. Because of this, the intake capacity of the program has reached 12.6 per cent from the total annual enrollment rate of higher education institutions in 2009. Nowadays, more than half of the total number of undergraduate students in higher education is enrolled in non-formal education that is a combination of distance, summer and extension courses programs.

Furthermore, Article 19 of the Higher Education proclamation No. 650/2009 declares that higher education institutions can offer education and training through continuing education and Distance in Ethiopia. Article 39 (2) of Harmonized Academic policy of Ethiopian Public higher education institutions also recognized evening,

\footnotetext{
${ }^{3}$ Article 2 (1) of the Higher Education Proclamation No. 351/2003, Addis Ababa, Negarit Gazette, 2003

${ }^{4}$ Ibid, Article 5
} 
distance and summer programs as forms of higher education. Besides, Article 45 (1-3) of Raya University senate legislation, for instance, stated that Continuing and Distance Education Program is important to increase access to higher education and to enable students to become more competitive in employment and personal enrichment through the use of innovative technology and quality customer service offered evening, summer and distance education in addition to regular fulltime program. So, establishing and expanding non-formal education is part and parcel of the mission and vision of higher education institutions.

In order to produce qualified and skilled manpower in the country higher education institutions have introduced harmonized curriculum, modular approach for course delivery, and quality assurance offices at each higher education institutions. The introduction of harmonized curriculum is introduced to address assessment method, pedagogical and content differences that may hold among the universities and colleges and to produce competent graduates from all programs in the market. This is to mean that all higher education programs at degree, master's and doctoral level are administered through the harmonized curriculum.

\section{Curriculum}

Curriculum is about what is intended by policy makers and curriculum committee; what is taught in classroom and what actually gets learnt by students. It is an educational compass that properly guides the direction of teaching -learning process of higher education institutions. So, designing a curriculum aims at enabling the learners to acquire pertinent scientific knowledge, independent thinking skills, communication skills and professional values that together prepare them to become competent professionals.

Pointing out this, Article 21 of Higher education Proclamation No. 650/2009 states that clustered higher education institutions, without contradicting with the national educational policy, have the power to design curriculum, mode of delivery, and assess learning outcomes. Similarly, Ministry of Education may have the role to coordinate curriculum development common to public institutions. Here, curriculum also determines content of the course/module and teaching material is prepared accordingly for all students enrolled in any education programs. This shows that the curriculum of all higher education programs is necessarily harmonized.

\section{Mode of Assessment and grading system}

Modes of delivery and assessment are normatively the same in all universities in the country. Accordingly to Article 56 of the Harmonized Academic policy of Ethiopian Public higher education institutions, the mode of assessment for higher education programs contains both continuous and summative assessment. Continuous assessment means assessing students' understanding in time of teaching-learning process through tests, reports, assignments, presentations, etc. In modular system, every module/course counts for $50 \%$ of the total module/course mark. While the summative assessment is administer at the end of the module/course. Cognizant of this, the mode of assessment is identical for all higher education programs (regular and continuing education). The same is true to the grading system of higher education programs. As to the Harmonized academic policy of Ethiopian public higher education institutions, the grading system ofall public and private higher education institutions is fixed.

\section{Procedures of Student Academic Promotion}

The status of student's academic achievement in higher education set on semester wise. Article 52 of the Harmonized Academic Policy stated that students in both regular and continuing education programs are promoted to the upcoming semester and academic year if and only if they register the minimum required competency in the higher education institutions.

\section{Load and credit requirement}

Article 45 of harmonized academic Policy stated that the semester load in higher education institutions may vary from program to program. The minimum semester load for regular program is 25 ECTS while the 32 is maximum semester load at normal circumstance. As to Article 46 of harmonized academic Policy, the semester load for continuing education program in evening and weekend students varies between 14 to 18 ECTS while the normal semester load in summer students is between 20 to 22 ECTS.

According to Article 48 of Harmonized Academic Policy, the total credit points required for three years bachelor program is between 150 ECTS and 180 ECTS, for four years bachelor program between 200 ECTS and 280 ECTS and for five years bachelor program between 250 ECTS and 350 ECTS.

So, all students in higher education institutions, regardless of the type of program, shall graduate when they satisfy the above mentioned course/module requirements and the minimum credit hours set by the respective academic unit at normal conditions. Additionally, Article 3 (16) of Harmonized Academic Policy and Article 125 of Raya University senate legislation stated that students of all higher education programs are required to have a Cumulative Grade Point Average (CGPA) of 2.00 and no "F" grade in any course/module taken for undergraduate program must be obtained. 


\section{Instructors' academic rank}

As Article 6 of the Harmonized Academic policy fixes the academic hierarchy of the academic staff of higher education institutions. These are Graduate Assistant I, Graduate Assistant II, Assistant Lecturer, Lecturer, Assistant Professor, Associate Professor and Professor. All academic staff, regardless of their rank, are collectively responsible to carry out the teaching learning process and then to equip academic and intellectual competency of students in all higher education programs. This is to mean that there is no higher education institutions' academic legislation that separately administers course offering procedures to regular and continuing and distance higher education programs.

\section{Academic Staff Recruitment criteria in higher education institutions in Ethiopia}

Ministry of education has circulated a letter to all higher education institutions especially the public ones to incorporate the ineligibility of the graduates of the all forms of non-formal education for lectureship competition. Regardless of the paper affiliated status of non-formal with the formal education in universities, the legislations of 44 higher education institutions in the country invalidate graduates of non-formal education programs (distance, evening and summer) are to compete for lectureship in higher education institutions merely due to their enrolment program.

Mekelle University, for instance, is one of the giant higher education institutions in Ethiopia. Article 29 (1(1)) of Mekelle University senate legislation stated that the academic staff recruitment procedure is strictly adopt and implement a merit based system. To the contrary, Article 30 (6) of Mekelle University senate legislation clearly indicated that any candidates who have completed their first and/or second degree in distance, evening, summer or par time program in "the University or from external institutions" shall not be considered for recruitment to any academic position in the university (MU, 2014).

Raya University, form the new universities inaugurated in 2017, in Article 55 of its senate legislation, states that candidates who have completed their first degree in distance, evening, summer or part time program in the University or from accredited/non-accredited private higher institutions shall not be considered for recruitment to any academic position (RU, 2017). This means, hundreds of thousands of non-formal education program graduates' job opportunity is limited to administrative staff in the institutions where they graduated from.

Generally, this contradicts with ESDP IV that expanded private higher education institutions as part of expansion of access to higher education in the country. These institutions have enrolled 3000 postgraduate students and the total enrolment at this level has reached 30,643 in 2014 accordingly.

\section{Conclusion}

Non-formal education (evening, distance and summer programs) has officially recognized as a higher education in Ethiopia. It becomes part of educational strategy designed to provide good quality higher education to a large number of students equitably and based on merit so as to meet the demand of the economy and the country at large. Higher education institutions have developed distance education provision procedures accordingly. At this time, it is part of the efforts of producing qualified and skilled manpower in the country higher education institutions. Specifically, higher education institutions' senate legislations confirmed its importance to increase access to higher education and to enable students to become more competitive in employment and personal enrichment through the use of innovative technology and quality customer service offered outside the regular fulltime program. This shows that establishing and expanding non-formal education i.e. evening, summer and distance programs is part and parcel of the mission and vision of higher education institutions.

Higher education institutions have jointly developed a harmonized curriculum for all academic programs in the country. Cognizant of this fact, they have developed identical modes of assessment, fixed the grading system, students, irrespective of their program, shall promote to the upcoming semester and academic year if and only if they register the minimum required competency in the higher education institutions and course/module requirements and the minimum credit hours in higher education institutions is identically the same.

All academic staff, regardless of their rank, are collectively responsible to carry out the teaching learning process and then to equip academic and intellectual competency of students in all higher education programs. This is to mean that there is not higher education institutions' academic legislation that separately administers course offering procedures to regular and continuing and distance higher education programs.

Higher education institutions, however, have been explicitly excluded candidates whose first degree and/or Master's degree is/are in distance, evening, summer or part time program in the University itself or from accredited/non-accredited private higher institutions shall not be considered for recruitment to any academic position.

Thus, the job opportunity of hundreds of thousands of the graduates of non-formal education program is limited to administrative staff at the institutions where they graduated from. This shows that there is policy inconsistence in employment opportunity of higher education graduates in the country in which the principles of senate legislations of higher education institutions contradict each other. 
Many of the higher education institutions have, according to the direction from Ministry of education, updated their senate legislation to exclude non-forma education program graduates from any academic position competition in a way that contradicts with the principle of merit-based system of placement.

To succinctly summarize, higher education institutions consider graduates of non-formal education programs (distance, evening and summer) ineligible to compete for lectureship in higher education institutions due to their enrolment program. This shows that there is paradox between the educational policy and practice in Ethiopian higher education institutions. Moreover, it is against the right of citizens to employ on the basis of meritocracy (merit-based) principle that has constitutional warranty.

\section{Recommendation}

Based on the analysis conducted regarding the status of non-formal education, policy direction and program of quality assurance of teachers and placement criteria of academic staff in higher education institutions in Ethiopia, the following recommendations are drawn for different stakeholders in education.

* Continuing education program has legal recognition as one higher education program dedicated to upgrade the professional qualification of teachers in the country. Therefore, the Ministry of Education should take the graduates of the program into account in any job competition as far as they are competent.

* In order to produce qualified and skilled professionals from all higher education programs, the Ministry of education in collaboration with higher education institutions should strengthen the capacity of the quality assurance office.

* As far as higher education institutions certified any student if and only if he/she fulfilled the required standards set in each academic discipline, they should set merit- based criteria that enable them to recruit competent and skillful academic staff.

* Higher education institutions should introduce more advanced screening mechanisms and entrance exam. Thus, university job vacancies for lectureship should bases on the competence of the applicants.

\section{Bibliography}

Abiyot, D. (2016). Higher Education Reforms, Shifting of Priority of Knowledge and Consequence for Academic Profession at Addis Ababa University. Public Sector Transformation and Development (pp. 211216). Addis Ababa: Ethiopian Civil Service University.

Carron, \& Hill, C. (1991). Non-formral education: Formation and Planning Issues. International Insitute for educational Planning.

Escrigas. (2008). Forward in GUNI Higher Education in the World 3.

ETP. (1994). Educaonal Policy and Training. St. George Printing Press: Negarit gazetta.

ETP. (1994). Educaonal Policy and Training. St. George Printing Press: Negarit gazetta.

HEP. (2009). Higher Education Proclamation. Addis Ababa: Federal Negarit Gazetta.

Hodgson, D. (1998). The Human Right to Education.

Marginson, S. (2008). Global settig, national policy and higher education. In S. Marginson, \& R. James, Education, Science and Public Policy: ideas for an Education Revoluion (pp. 87-112). Australia: Melbourne University Publishing.

MOE. (2002/3). Educational Statistics Annual Abstrat. Addis Ababa: Minisry of Education.

MOE. (2003). Proclamation No. 351/2003. Addis Ababa: FEDERAL NEGARIT GAZETA.

MoE. (2005). ESDP III. Addis Ababa: MoE.

MoE. (2010). ESDP IV. Addis Ababa: MoE.

MoE. (2015). ESDP $V$. Addis Ababa: MoE.

Moran, T. (2008). Education, Science and Innovation. In S. Marginson, \& R. James, Education, Science and Public Policy: Ideas for an Education Revolution (pp. 12-24). VIctoria: Melbourne University .

MU. (2014). Mekelle University Senate legislation. Mekelle: MU.

Negash, T. (2006). Education in Ethiopia: From Crisis to Brink of Collapse. Appsala: Nordiska.

O.Olaniyi, F. (2015). The Relevance of learning Theories in Adult and Non-formal Education. Journal of Educational and Social Research, 261-264.

Pring, R. (2004). Philosophy of Education: Aims, theory, Commonsense and Research . London: British Library. RU. (2017). RAya University Senate legislation. Maichew: RU.

Russell, S. T. (2001). The Developmental Benefits of Non-formal Education and Youth Development,. Summer, pp. $1-12$.

Singh, R. R. (1991). Education for the 21st century: Asian-Pacific Perspectives. Thialand : UNESCO Publishers. Thomson. (2008). Exploring the relationship between higher education and Development. 